San Jose State University

SJSU ScholarWorks

Master's Theses

Master's Theses and Graduate Research

1989

\title{
REM sleep deprivation alters the cyclic occurrence of food consumption in laboratory rats
}

Randall K. Martinez

San Jose State University

Follow this and additional works at: https://scholarworks.sjsu.edu/etd_theses

\section{Recommended Citation}

Martinez, Randall K., "REM sleep deprivation alters the cyclic occurrence of food consumption in laboratory rats" (1989). Master's Theses. 3095.

DOI: https://doi.org/10.31979/etd.p2rm-r5pp

https://scholarworks.sjsu.edu/etd_theses/3095

This Thesis is brought to you for free and open access by the Master's Theses and Graduate Research at SJSU ScholarWorks. It has been accepted for inclusion in Master's Theses by an authorized administrator of SJSU ScholarWorks. For more information, please contact scholarworks@sjsu.edu. 


\section{INFORMATION TO USERS}

The most advanced technology has been used to photograph and reproduce this manuscript from the microfilm master. UMI films the text directly from the original or copy submitted. Thus, some thesis and dissertation copies are in typewriter face, while others may be from any type of computer printer.

The quality of this reproduction is dependent upon the quality of the copy submitted. Broken or indistinct print, colored or poor quality illustrations and photographs, print bleedthrough, substandard margins, and improper alignment can adversely affect reproduction.

In the unlikely event that the author did not send UMI a complete manuscript and there are missing pages, these will be noted. Also, if unauthorized copyright material had to be removed, a note will indicate the deletion.

Oversize materials (e.g., maps, drawings, charts) are reproduced by sectioning the original, beginning at the upper left-hand corner and continuing from left to right in equal sections with small overlaps. Each original is also photographed in one exposure and is included in reduced form at the back of the book. These are also available as one exposure on a standard $35 \mathrm{~mm}$ slide or as a $17^{\prime \prime}$ x $23^{\prime \prime}$ black and white photographic print for an additional charge.

Photographs included in the original manuscript have been reproduced xerographically in this copy. Higher quality $6^{\prime \prime} \times 9^{\prime \prime}$ black and white photographic prints are available for any photographs or illustrations appearing in this copy for an additional charge. Contact UMI directly to order.

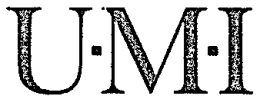



Order Number 1337829

REM sleep deprivation alters the cyclic occurrence of food consumption in laboratory rats

Martinez, Randall Kent, M.A.

San Jose State University, 1989 



\title{
REM SLEEP DEPRIVATION ALTERS THE CYCLIC OCCURRENCE OF FOOD CONSUMPTION IN LABORATORY RATS
}

\author{
A Thesis \\ Presented to \\ the Faculty of the Department of Psychology \\ San Jose State University
}

In Partial Fulfillment

of the Requirements for the Degree

Master of Arts

by

Randall K. Martinez

May, 1989 


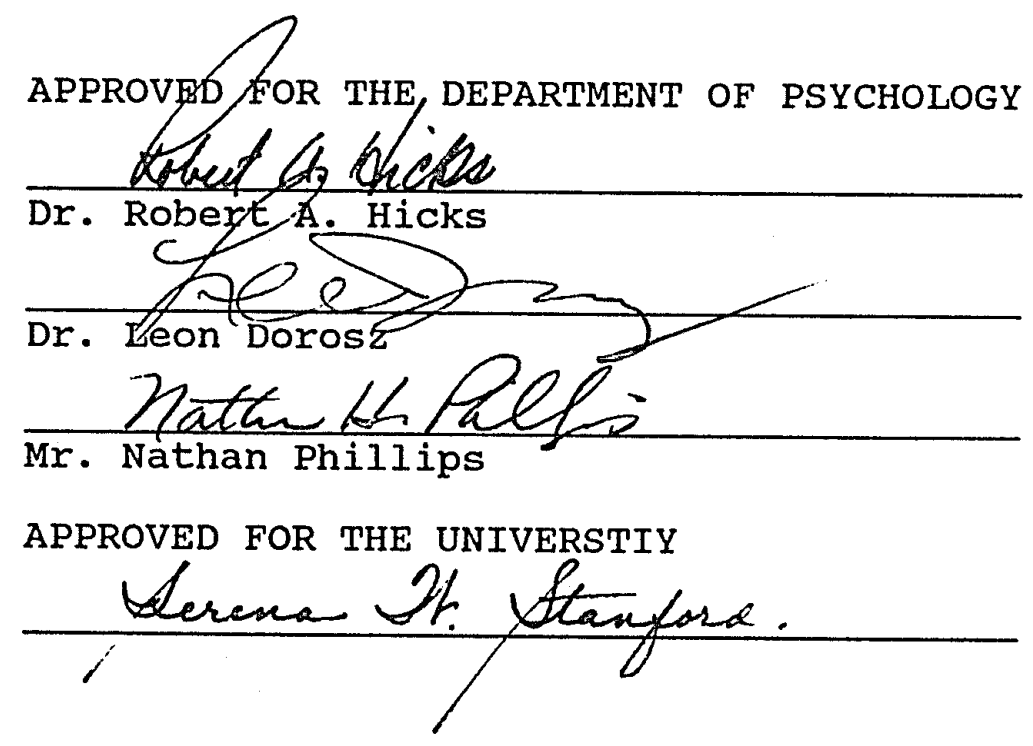




\section{ACKNOWLEDGEMENTS}

I wish to thank Dr. Robert Hicks for his utmost guidance and support throughout this project and my committee members Nathan Phillips and Dr. Leon Dorosz for their commitment to this endeavor. I would also like to thank John Empey for his technical assistance in the development of the feeding apparatus. This study was supported by NIH-MBRS Grant RR08192-09. 
TABLE OF CONTENTS

SECTION

PAGE

INTRODUCTION $\ldots \ldots \ldots \ldots \ldots \ldots \ldots \ldots \ldots \ldots \ldots \ldots \ldots \ldots \ldots$

Statement of the Problem and Purpose .......... 4

REVIEW OF IITERATURE $\ldots \ldots \ldots \ldots \ldots \ldots \ldots \ldots \ldots \ldots \ldots \ldots$

Eating Subsequent to Natural Fluctuations in RS .. 5

REM Deprivation and Food Intake ............ 6

Possible RSD Method Confounding ............. 8

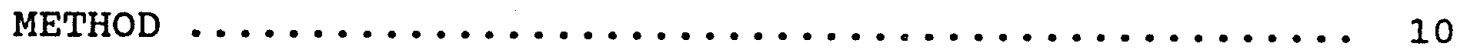

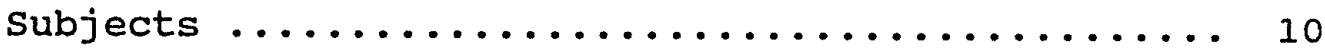

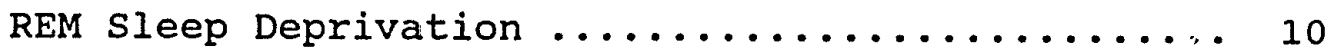

Monitoring of food Intake ................ 11

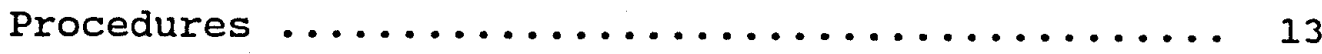

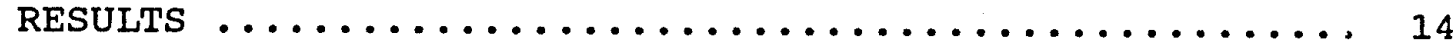

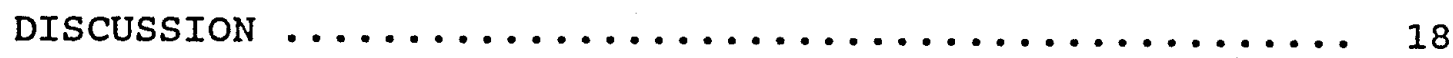

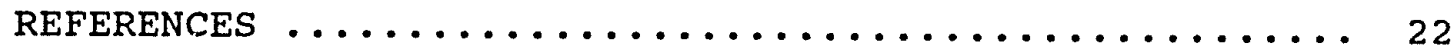

APPENDICES $\ldots \ldots \ldots \ldots \ldots \ldots \ldots \ldots \ldots \ldots \ldots \ldots \ldots \ldots \ldots \ldots \ldots$

Appendix A. Summary Table of Analysis of Bodyweight Data including post hoc Analyses ................... 24

Appendix B. Summary Table of Analysis of 24 hour Food Consumption Data ............ 26

Appendix C. Summary Tables of Analyses of Light Period and Dark Period Food Consumption Data ............. 27

Appendix D. Summary Table of Analysis of Light/ Dark Differences in Food Consumption including post hoc Analyses ....... 28 


\section{IIST OF TABLES}

\section{TABLE}

1. Mean Daily Bodyweights (g) and Standard Deviations for each Treatment Group on each of the ten

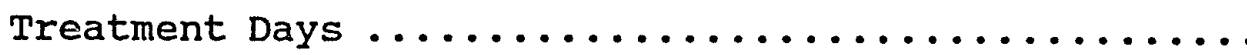

2. Mean Total Food Consumption (no. of pellets) and Standard Deviations for each Treatment Group on each of the ten Treatment Days .............. 15

3. Mean Food Consumption (no. of pellets) and Standard Deviations for each Treatment Group for each 12 hour Light and 12 hour Dark Period for each of the ten Treatment Days ................. 16

4. Mean Differences in Food Consumption (no. of pellets) and Standard Deviations between each 12 hour Light and 12 hour Dark Period for each Treatment Group on each of the ten Treatment Days $\ldots \ldots \ldots \ldots \ldots \ldots \ldots \ldots \ldots \ldots \ldots$ 
1. Diagram of a bucket and feeder with a small platform in place ..................... 12 


\author{
REM SLEEP DEPRIVATION ALTERS THE CYCLIC OCCURRENCE \\ OF FOOD CONSUMPTION IN LABORATORY RATS \\ Randall K. Martinez \\ San Jose State University
}

Running head: REM DEPRIVATION ALTERS CYCLIC FEEDING

Footnotes

Requests for reprints should be sent to Randall Martinez, Department of Psychology, San Jose State University, San Jose, California 95192 . 
REM and Feeding

Abstract

Because of ambiguities in previous studies of REM sleep deprivation (RSD) and feeding behavior, fifteen male spragueDawley rats were divided into control and REM deprived groups. The food consumption, for 10 consecutive 24 hour periods, of each rat was continuously monitored. There was no difference in total daily food consumption between REM deprived rats and untreated control animals. REM deprived rats did exhibit greater food consumption than controls during the 12 hour light periods of each REM deprivation day and lower food consumption throughout the 12 hour dark intervals of the RSD and recovery periods. Thus, REM deprived rats had smaller light/dark differences in food consumption than untreated animals, and these differences remained disturbed subsequent to the termination of RSD. 
REM and Feeding

REM Sleep Deprivation Alters the Cyclic Occurrence of Food Consumption in Laboratory Rats

An interesting assertion that has been advanced as a partial explanation of the behavioral functions of REM sleep (RS) is that this stage of sleep plays a role in the modulation of the level of generalized drive (Vogel, 1979). In his discussion of this theory, vogel stated that, "In animals, RSD (REM sleep deprivation) increases such drive motivated behaviors as sex, aggression, pleasure seeking, food seeking, and grooming." He then elaborated this point by stating that "A motivational function of RS is inferred fromi these observations that RSD increases drive motivated behavior" (p. 234). Put differently, Vogel has suggested that RSD increases the level of generalized drive and this inference is validated by data from studies which have demonstrated that RSD potentiates primary drive-linked behavior.

Probably the clearest evidence that can be marshalled to support this aspect of Vogel's theory are the results of several studies that measured the relationships between RS and the eating behaviors of animals (e.g. Bergman, Kushida, Hennessy, Winter, \& Rechtschaffen, 1984; Bowersox, Baker, \& Demerit. 1984; Dement, 1965; Elomaa, 1985; Elomaa \& Johansson, 1980; Siegal, 1975). Specifically, most of these data suggest that there is an inverse relationship between amount of RS and 
subsequent food intake. However, as the review of this literature will show, there are sufficient ambiguities in each of the studies to warrant further investigation of this relationship.

\section{Statement of the Problem and the Purpose}

The greatest portion of the research in this area was done by Elomaa and his colleagues (See Elomaa, 1985 for a review). A purpose of this study, then, was to replicate their results in a manner that would correct for certain flaws in their procedures and thereby provide less ambiguous evidence for the hypothesis that RSD potentiates primary drive-linked behavior. Thus, congruent with the bulk of existing literature, these hypotheses were formed:

$\mathrm{H}_{1}$ : Compared to the untreated controls, the REM-deprived animals would consume more food.

$\mathrm{H}_{2}$ : Compared to the untreated controls, the REM-deprived animals would show an alteration in eating behavior so that the differences between the amount eaten during the light and dark periods would be reduced.

Review of Literature

As is stated in the previous section, most of the literature that can be marshalled to support Vogel's RSGeneralized Drive Hypothesis has been derived by measuring the relationship between $\mathrm{RS}$ and eating in laboratory animals. These studies have followed either one of two designs, i.e., studies which monitored eating subsequent to natural 
variations in $\mathrm{RS}$ or studies which monitored eating as a function of RSD. Each of these groups of studies will be reviewed in the following section.

Eating subsequent to natural fluctuations in RS

In the seminal study of this type, seigal (1975) computed the relationship between natural fluctuations in RS and food consumption in a group of six cats. To do this, he continuously monitored certain sleep and food intake parameters of these animals that ranged from five to nine days. As a result of these observations, seigal concluded that, "In all but one of the cats, the correlation between REM sleep and subsequent food intake was negative. REM sleep was a better predictor of food intake than either waking, slow wave sleep, or previous food intake" (p.399). Seigal's data are quite impressive, for in spite of the small number of occasions that were available for the computation of the correlations for each animal, four of the six correlation coefficients that he computed between RS and subsequent food intake were significant and the median correlation between these variables for all animals was -.79 .

In a more recent study, Bowersox, et al. (1984) attempted to replicate seigal's research. They computed negative correlations between RS and subsequent food intake for three of their five animals, however, none of their correlation coefficients were significantly different than 
REM and Feeding

zero. These data led Bowersox and his colleagues to conclude that, "... this study found no consistent evidence that in the undisturbed animal, food consumption is related quantitatively to daytime/nighttime expression of any sleep or waking variable" (p. 909). In rationalizing the difference between their results and seigal's, they noted that these were difficult to explain and could not be attributed to the minor procedural differences between the two studies. Thus, if it exists, the relationship between natural fluctuations in RS and subsequent food intake is not as strong as seigal first claimed.

REM deprivation and food intake

In the first study of its kind, Dement (1965) measured the relationship between $\mathrm{RSD}$ and subsequent food intake in cats. He reported the results of this work as a presented paper, and unfortunately, the only written record of it is the following abstract of that paper.

Seventeen cats had their food intake carefully measured. By comparison with control cats, there was only some slight trend for the deprived cats to eat more. However, the reverse procedure (i.e., starvation) was attempted, and the motivation to eat was strikingly increased in REM-deprived cats as opposed to controls. (p. 406)

Thus, Dement noted a modest negative correlation between RS and food intake that is consistent with the collective results of Seigal and Bowersox, et al. He also claimed that RSD augmented the effects that food deprivation has on subsequent 
REM and Feeding

food intake.

More recently, Elomaa and Johansson (1980) continuously monitored the feeding behavior of eight male rats for a period of eight days. They reported that during the RSD period, their animals increased food intake by $32 \%$ as compared to baseline, ate more frequently, and showed a pronounced reduction in the difference in food intake between the light and dark periods of the light cycle. In a subsequent replication of this study, Elomaa (1981) reported that during RSD, his animals showed no significant increases in food intake, but consistent with Elomaa and Johansson's data, during RSD, the animals ate more frequently and the light/dark difference in meal size was abolished. In this paper, Elomaa explained the discrepancy in the RSD-food intake relationships in these studies by asserting that, in the former, his animals were only partially REM deprived (he stated $50 \%$ ) while in the latter, he argued that his animals were totally REM deprived. He did not attempt to explain the nature of the underlying mechanism that would cause partial RSD to affect food intake differently than complete RSD. Further, both of these studies were not designed to include electrophysiological measures of sleep; thus, presumed differences in RS between these groups is his post hoc assumption.

In a more recent overview of his work, Elomaa (1985) qualified his previous conclusions concerning the effects of 
REM and Feeding

RSD on food consumption by stating that RSD "... does not induce true hyperphagia but on the contrary may interfere with the ability of the organism to adapt to increased energy demands" (p. 26).

A recent study by Bergmann and his colleagues (1984) further complicates interpretation of the relationship between RSD and eating in laboratory animals. They deprived rats of RS (deprivation was almost total, i.e., 1.3\% of baseline) chronically, until the animals died, and reported that during the deprivation period, average food intake increased by $186.2 \%$ over baseline levels. In contrast to the results of Elomaa's (1981) study, these data suggest that total RSD may potentiate substantial increases in food intake.

Possible RSD method confounding

Clearly, the results of the studies considered here are in conflict. Perhaps, to a degree the differing conclusions can be attributed to the differential effects of the RSD procedures which were used in these studies. To explain, Elomaa and Johansson (1980) used a RSD technique which they had developed, i.e., the "cuff-pedestal" technique which is somewhat different from the water tank method that is typically used in these kinds of studies. Their technique induced substantial weight loss (E. Elomaa, personal communication, 1980). In his later study, Elomaa (1981) initiated some refinements in his procedures which reduced 
weight loss. In their study, Bergmann et al. (1984) used a RSD technique, which they developed, that involved placing the animal on a horizontal disk which rotated at the onset of $\mathrm{RS}$. This forced the animal to awaken and move to avoid falling into a pool of water. Like the "cuff-pedestal" method used by Elomaa and Johansson, exposure to this procedure was associated with a substantial loss in weight. Thus, in both the Elomaa and Johansson and Bergmann et al. studies, novel RSD methodologies were used which, unlike the widely used water tank technique, produced substantial weight loss (see Hicks \& Moore, 1979; Hicks, Gomez, Gonzales, Kuroda, Orme, \& Reyes, 1981; Hicks, Hirshfield, Humphrey, Lauber, Giampaoli, \& Hawkins, 1981). In this regard it should be noted that excessive weight loss could be an index of exposure to a stressor and/or a sign that the feeding procedures which were used, prevented these animals from obtaining adequate nutrition. Either of these possibilities should be viewed as a source of confounding, and, since this is the case, the relationship between $\mathrm{RS}$ and eating must be viewed as ambiguous. Therefore, the purpose of this study was to measure the relationships between RSD and certain eating parameters in a manner that minimized the sources of confounding which have beclouded the interpretation of the results of previous studies. 
REM and Feeding

Method

\section{Subjects}

Fifteen male spraque-Dawley rats were used for this experiment. They were 60 days old and weighed approximately $270 \mathrm{~g}$ when the monitoring of food intake began. Each was individually housed in buckets with wood shavings and a large platform for a seven day lab acclimatization period plus a seven day feeder apparatus adaptation period. After this adaptation period, the animals were randomly assigned to one of three treatment conditions, i.e., a dry control (DC) group, a wet control (WC) group, or a RSD group, so that there were five animals in each group.

\section{REM Sleep Deprivation}

RSD was achieved by using the relatively non-stressful water tank procedure (Hicks \& Moore, 1979). Throughout the experiment, all of the animals were housed in $18.9 \mathrm{~L}$ buckets with food and water available ad lib from a feeder and a water bottle positioned through the side of the bucket. During the treatment period, these buckets were used for RSD and to achieve the necessary controls, as described in the next paragraph.

Following the adaptation period, food intake was monitored during a two day baseline period, in which all animals were in the dry condition. A four day treatment period then followed, in which the RSD group was placed on 
REM and Feeding

small $(6.5 \mathrm{~cm})$ platforms surrounded by water. When these animals entered REM sleep, they lost muscle tonus and made contact with the water. This procedure deprived them of REM sleep (Mendelson, Guthrie, Frederick, \& Wyatt, 1974). The WC group was placea on large $(16.5 \mathrm{~cm})$ platforms surrounded by water. The large platforms minimize contact with the water due to muscle atonia associated with REM sleep onset and thus this group served as a control for exposure to a wet environment. The water level for the RSD and the WC groups was $1 \mathrm{~cm}$ below the top of the platform. The DC group remained in the original housing conditions during the four day treatment period, and al.l the animals were then returned to the original housing conditions for the four day recovery period.

\section{Monitoring of Food Intake}

The food intake monitoring system was especially constructed for this study. The feeder was a plastic block with a $2 \mathrm{~cm}$ diameter by $1 \mathrm{~cm}$ deep cone-shaped feeding trough drilled into the top of it. This block was mounted into the side of the bucket (See Figure 1). Photo beam sensors attached on either side of the feeder trough were plugged into a Colbourn Photobeam Detector (\#523-01), a colbourn one-shot (\#552-02), and a Colbourn Electronic counter (\#523-25). These instruments were wired to a Davis Scientific Instruments Food Dispenser (\#PD-104) and interfaced with an Apple IIe computer 


\section{Figure 1}

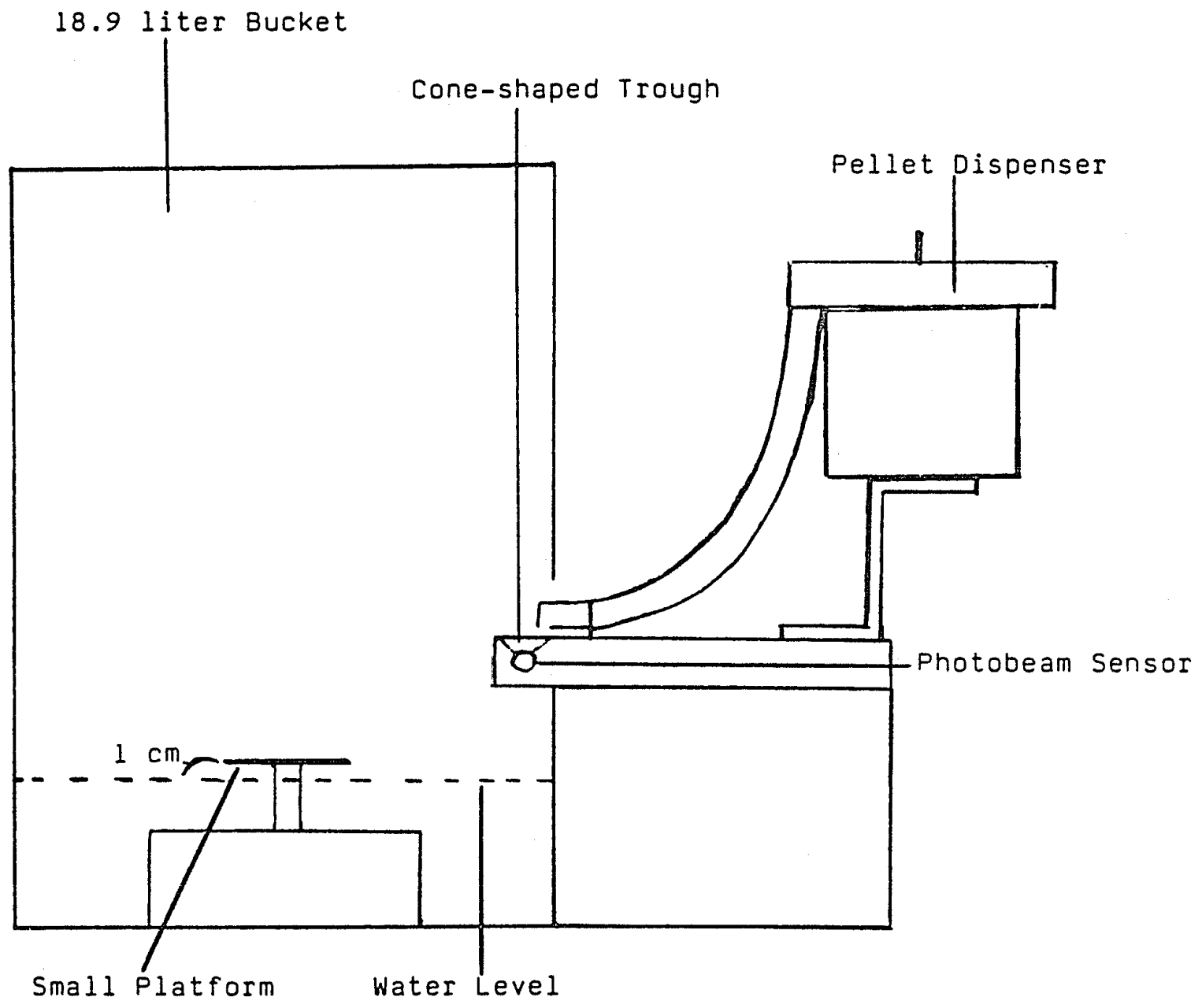

Diagram of Bucket and Feeder with a Small Platform in place. 
REM and Feeding

programmed to keep time, count the number of food pellets dispensed food, store data on a floppy disk, and print out data.

When a rat took a food pellet (Noyes $45 \mathrm{mg}$, Formula A) from the cone-shaped trough, the photobeam woul l detect it. A signal was then relayed through the colbourn instruments to the food dispenser and another pellet was released. Thus, there was always a food pellet in the feeder trough available for the animal. It should be noted that this system was evolved through considerable empirical observation. Thus, the system described here provided easy access to food and almost eliminated any mechanical problems in the delivery of food. procedures

The animals were 46 days old upon arrival from the supplier. The lab temperature was $26^{\circ} \mathrm{C}, \pm 1^{\circ} \mathrm{C}$, and there was a 12:12 hour light:dark cycle with the lights on at 0800 hours. Each animal was weighed and handled for a five minute period on each adaptation day, and the eating monitor was introduced to each rat one week prior to the commencement of data collection to insure consistent weight gain. collection of the data was begun at the end of the adaptation period, and the animals were randomly assigned to one of the three treatment conditions. Monitoring of food intake was begun at 1400 hours on the first baseline day and continued until 1400 hours on the last recovery day. Except for a daily one hour 
REM and Feeding

period to clean the buckets, add food pellets, weigh the animals, and change the water there was no disruption of the food intake recording. The computer was programmed to count the number of pellets taken per minute and it stored the data on a disk every 30 minutes. The computer would also printout the data every 24 hours. The feeding apparatus and the computer were checked frequently throughout the day to insure proper operation. Also, the animals were kept in a red-light condition during the dark cycle to allow for nighttime checks by the experimenter.

\section{Results}

Table 1 summarizes the bodyweights for each treatment group for each day of the 10-day treatment period.

TABLE 1

MEAN DAILY BODYWEIGHTS (no. Of pellets) AND STANDARD DEVIATIONS FOR EACH TREATMENT GROUP ON EACH OF THE TEN TREATMENT DAYS

\begin{tabular}{|c|c|c|c|c|c|c|c|c|c|c|}
\hline & \multicolumn{2}{|c|}{ Basel ine } & \multicolumn{4}{|c|}{ REM Deprivation } & \multicolumn{4}{|c|}{ Recovery } \\
\hline & 1 & 2 & $\overline{3}$ & 4 & 5 & $\frac{6}{6}$ & 7 & $\overline{8}$ & 9 & 10 \\
\hline $\begin{array}{r}\text { RSD } \\
\text { sd }\end{array}$ & $\begin{array}{l}266.8 \\
\pm 16.7\end{array}$ & $\begin{array}{r}271.4 \\
\pm 17.8\end{array}$ & $\begin{array}{r}264.9 \\
\pm 15.7\end{array}$ & $\begin{array}{c}265.2 \\
\pm 18.2\end{array}$ & $\begin{array}{r}263.5 \\
\pm 13.3\end{array}$ & $\begin{aligned} & 265.8 \\
\pm & 12.2\end{aligned}$ & $\begin{array}{r}270.4 \\
\pm 13.5\end{array}$ & $\begin{array}{r}276.0 \\
\pm 16.0\end{array}$ & $\begin{array}{r}278.7 \\
\pm 14.4\end{array}$ & $\begin{array}{r}283.5 \\
\pm 14.6\end{array}$ \\
\hline $\begin{array}{l}\text { WC } \\
\text { sd }\end{array}$ & $\begin{array}{r}278.5 \\
\pm 12.7\end{array}$ & $\begin{array}{r}279.5 \\
\pm 16.4\end{array}$ & $\begin{array}{r}287.1 \\
\pm 13.7\end{array}$ & $\begin{array}{l}286.5 \\
\pm 16.8\end{array}$ & $\begin{array}{l}289.6 \\
\pm 14.1\end{array}$ & $\begin{array}{r}294.3 \\
\pm 14.2\end{array}$ & $\begin{array}{l}295.3 \\
\pm 16.3\end{array}$ & $\begin{array}{r}301.1 \\
\pm 27.3\end{array}$ & $\begin{array}{r}305.4 \\
\pm 16.9\end{array}$ & $\begin{array}{r}308.7 \\
\pm 19.2\end{array}$ \\
\hline $\begin{array}{l}\text { DC } \\
\text { sd }\end{array}$ & $\begin{array}{l}255.7 \\
\pm 29.8\end{array}$ & $\begin{array}{r}266.2 \\
\pm 31.0\end{array}$ & $\begin{array}{r}272.6 \\
\pm 30.6\end{array}$ & $\begin{array}{l}279.9 \\
\pm 29.0\end{array}$ & $\begin{array}{r}284.8 \\
\pm 29.5\end{array}$ & $\begin{array}{r}293.5 \\
\pm 29.7\end{array}$ & $\begin{array}{r}295.3 \\
\pm 28.5\end{array}$ & $\begin{array}{r}298.5 \\
\pm 26.2\end{array}$ & $\begin{array}{l}305.9 \\
\pm 27.2\end{array}$ & $\begin{array}{r}308.6 \\
\pm 29.1\end{array}$ \\
\hline
\end{tabular}

The data summarized in Table 1 were first analyzed by computing a three (treatments) by ten (days) mixed factor 
REM and Feeding

ANOVA (See Appendix A for the summary table of this analysis). The effect of treatments on bodyweight was not significant $(\underline{F}(2,12)=1.52)$. The main effect for days was significant $(\underline{F}(9,18)=53.09, \underline{p}<.01)$, as was the treatment by days interaction $(\underline{F}(18,108)=7.37, \underline{p}<.01)$. These results were expected and are thought to reflect these animals' normal growth over the time period covered by this study. Thus, these data suggest that RSD does not reliably alter bodyweight in rats.

Table 2 summarizes the total food consumption for each treatment group for each 24 hour interval of the 10 day treatment period.

TABLE 2

MEAN TOTAL FOOD CONSUMPTION (no. Of pellets) AND STANDARD DEVIATIONS FOR EACH TREATMENT GROUP ON EACH OF THE TEN TREATMENT DAYS

\begin{tabular}{|c|c|c|c|c|c|c|c|c|c|c|}
\hline \multirow{2}{*}{\multicolumn{3}{|c|}{$\begin{array}{lr}\text { Baseline } \\
1\end{array}$}} & \multicolumn{4}{|c|}{ REM Deprivation } & \multirow{2}{*}{\multicolumn{4}{|c|}{ Recovery }} \\
\hline & & & 3 & 4 & 5 & $\overline{6}$ & & 8 & 9 & $\overline{10}$ \\
\hline $\begin{array}{r}\text { RSD } \\
\text { sd }\end{array}$ & $\begin{array}{r}538.4 \\
\pm 63.5\end{array}$ & $\begin{array}{l}521.0 \\
\pm 79.5\end{array}$ & $\begin{array}{l}584.2 \\
\pm 99.1\end{array}$ & $\begin{array}{l}519.0 \\
\pm 94.7\end{array}$ & $\begin{array}{r}603.8 \\
\pm 59.5\end{array}$ & $\begin{array}{r}627.4 \\
\pm 27.8\end{array}$ & $\begin{array}{l}377.2 \\
\pm 48.3\end{array}$ & $\begin{array}{r}449.8 \\
+38.8\end{array}$ & $\begin{array}{l}460.8 \\
\pm 51.7\end{array}$ & $\begin{array}{l}461.4 \\
\pm 45.1\end{array}$ \\
\hline $\begin{array}{l}\text { WC } \\
\text { sd }\end{array}$ & $\begin{array}{l}547.0 \\
\pm 63.0\end{array}$ & $\begin{array}{l}528.4 \\
\pm 80.2\end{array}$ & $\begin{array}{r}638.8 \\
\pm 69.4\end{array}$ & $\begin{array}{l}522.0 \\
\pm 29.9\end{array}$ & $\begin{array}{l}586.2 \\
\pm 168\end{array}$ & $\begin{array}{r}570.0 \\
\pm 97.1\end{array}$ & $\begin{array}{r}443.8 \\
\pm 61.2\end{array}$ & $\begin{array}{l}503.6 \\
\pm 76.0\end{array}$ & $\begin{array}{l}518.4 \\
\pm 86.4\end{array}$ & $\begin{array}{l}494.6 \\
\pm 76.8\end{array}$ \\
\hline $\begin{array}{l}\text { DC } \\
\text { sd }\end{array}$ & $\begin{array}{r}500.2 \\
\pm 56.8\end{array}$ & $\begin{array}{r}552.2 \\
\pm 42.0\end{array}$ & $\begin{array}{r}512.2 \\
\pm 44.8\end{array}$ & $\begin{array}{r}528.0 \\
\pm 43.5\end{array}$ & $\begin{array}{r}512.4 \\
\pm 43.2\end{array}$ & $\begin{array}{r}548.2 \\
\pm 76.8\end{array}$ & $\begin{array}{r}508.6 \\
\pm 78.3\end{array}$ & $\begin{array}{r}500.2 \\
\pm 55.9\end{array}$ & $\begin{array}{r}504.6 \\
\pm 58.1\end{array}$ & $\begin{array}{r}479.6 \\
\pm 25.3\end{array}$ \\
\hline
\end{tabular}

The data summarized in Table 2 were analyzed by computing a three (treatments) by ten (days) mixed factor ANOVA, and the 
results of this analysis are summarized in Appendix B. As can be seen by inspecting the summary of this analysis, both the main effect for treatments and the treatment by days interaction were not significant. However, a significant main effect for days was computed $(\underline{F}(9,108)=8.36, \underline{p}<.01)$. This result, like the bodyweight result mentioned above, probably reflects a systematic change that is associated with the growth of these relatively young animals over the experimental period.

Table 3 summarizes the total food consumption for each treatment group for each 12 hour light interval and 12 hour dark interval for the 10 day treatment period.

TABLE 3

\begin{tabular}{|c|c|c|c|c|c|c|c|c|c|}
\hline \multirow{2}{*}{\multicolumn{2}{|c|}{$\begin{array}{r}\text { MEAN FOOD C } \\
\text { TREATMENT GROUP F } \\
\begin{array}{l}\text { Baseline } \\
1\end{array} 2\end{array}$}} & & REM & riva & & & & & \\
\hline & & 3 & 4 & 5 & 6 & 7 & 8 & $\overline{9}$ & 10 \\
\hline $\begin{array}{r}\text { L } 150.2 \\
\text { sd } \pm 31.1\end{array}$ & $\begin{array}{l}150.0 \\
\pm 50.3\end{array}$ & $\begin{array}{l}236.8^{\circ} \\
\pm 77.1\end{array}$ & $\begin{array}{r}213.2 \\
\pm 32.3\end{array}$ & $\begin{array}{r}230.0 \\
\pm 30.9\end{array}$ & $\begin{array}{r}236.0 \\
\pm 23.7 \\
\end{array}$ & $\begin{array}{r}77.2 \\
\pm 39.8 \\
\end{array}$ & $\begin{array}{r}124.2 \\
\pm 63.2\end{array}$ & $\begin{array}{r}106.4 \\
\pm 23.3\end{array}$ & $\begin{array}{l}206.4 \\
\pm 33.7\end{array}$ \\
\hline $\begin{array}{r}\text { D } 388.2 \\
\text { sd } \pm 48.6\end{array}$ & $\begin{array}{l}371.0 \\
\pm 86.8\end{array}$ & $\begin{array}{r}347.4 \\
\pm 34.1\end{array}$ & $\begin{array}{l}305.8 \\
\pm 75.6\end{array}$ & $\begin{array}{r}373.8 \\
\pm 36.5\end{array}$ & $\begin{array}{l}391.4 \\
\pm 36.1\end{array}$ & $\begin{array}{r}300.0 \\
\pm 63.9\end{array}$ & $\begin{array}{r}325.6 \\
\pm 75.5\end{array}$ & $\begin{array}{r}354.4 \\
\pm 49.6\end{array}$ & $\begin{array}{r}355.0 \\
\pm 53.2\end{array}$ \\
\hline $\begin{array}{r}83.6 \\
\text { sd } \pm 51.2\end{array}$ & $\begin{array}{r}86.6 \\
\pm 54.7 \\
\end{array}$ & $\begin{array}{r}245.4 \\
\pm 72.2 \\
\end{array}$ & $\begin{array}{r}134.8 \\
\pm 40.8\end{array}$ & $\begin{array}{r}119.8 \\
+75.1 \\
\end{array}$ & $\begin{array}{r}150.0 \\
\pm 47.0 \\
\end{array}$ & $\begin{array}{r}59.2 \\
\pm 61.2 \\
\end{array}$ & $\begin{array}{r}95.6 \\
\pm 48.9 \\
\end{array}$ & $\begin{array}{r}74.6 \\
\pm 23.0\end{array}$ & $\begin{array}{r}69.2 \\
\pm 29.6\end{array}$ \\
\hline $\begin{array}{r}\text { D } 463.4 \\
\text { sd } \pm 43.9\end{array}$ & $\begin{array}{r}442.8 \\
\pm 39.6\end{array}$ & $\begin{array}{r}393.4 \\
\pm 56.5\end{array}$ & $\begin{array}{r}386.0 \\
\pm 27.5\end{array}$ & $\begin{array}{l}466.4 \\
\pm 165\end{array}$ & $\begin{array}{l}400.0 \\
\pm 125\end{array}$ & $\begin{array}{r}384.6 \\
\pm 29.5\end{array}$ & $\begin{array}{r}400.4 \\
\pm 37.0\end{array}$ & $\begin{array}{r}443.8 \\
\pm 64.6\end{array}$ & $\begin{array}{r}425.4 \\
\pm 47.5\end{array}$ \\
\hline $\begin{array}{r}\text { L } 118.0 \\
\text { 8d } \pm 49.8\end{array}$ & $\begin{array}{r}153.4 \\
\pm 45.7\end{array}$ & $\begin{array}{r}101.8 \\
\pm 31.5 \\
\end{array}$ & $\begin{array}{r}102.0 \\
\pm 72.4\end{array}$ & $\begin{array}{r}91.2 \\
\pm 24.7 \\
-\end{array}$ & $\begin{array}{r}99.6 \\
\pm 35.8\end{array}$ & $\begin{array}{r}73.6 \\
\pm 30.8 \\
\end{array}$ & $\begin{array}{r}74.0 \\
\pm 37.6 \\
\end{array}$ & $\begin{array}{r}70.6 \\
\pm 33.1 \\
\end{array}$ & $\begin{array}{r}76.8 \\
\pm 40.4 \\
\end{array}$ \\
\hline $\begin{array}{r}\text { D } 382.2 \\
8 d \pm 64.1\end{array}$ & $\begin{array}{r}398.8 \\
\pm 59.4\end{array}$ & $\begin{array}{r}420.4 \\
\pm 46.4\end{array}$ & $\begin{array}{r}426.0 \\
\pm 68.4\end{array}$ & $\begin{array}{r}413.4 \\
\pm 53.7\end{array}$ & $\begin{array}{r}448.4 \\
\pm 71.3\end{array}$ & $\begin{array}{l}435.0 \\
\pm 69.3\end{array}$ & $\begin{array}{r}416.0 \\
\pm 43.4\end{array}$ & $\begin{array}{r}434.0 \\
\pm 36.7\end{array}$ & $\begin{array}{r}402.8 \\
\pm 31.0\end{array}$ \\
\hline
\end{tabular}

The data summarized in Table 3 were analyzed by computing separate three (treatment) by ten (days) mixed factor ANOVAs 
for the light and dark period data. The results of these analyses are summarized in Appendix c. As expected, the analysis for the light interval data revealed significant main effects for treatments $(\underline{F}(2,12)=6.77, \underline{p}<.05)$, for days $(\underline{F}(9,108)=21.05, \underline{p}<.01)$, and a significant treatment by days interaction $(\underline{F}(18,108)=6.95, \underline{p}<.01)$. The summary of the analysis for the dark interval data revealed only a significant main effect for treatments $(\underline{F}(2,12)=6.20, \underline{p}<.05)$. Thus, these data demonstrate greater light interval food consumption for REM deprived rats during the 4 day RSD period, and lower dark interval food consumption for REM deprived rats throughout the 4 day RSD period and the 4 day recovery period.

Table 4 summarizes the differences in the food consumption between the 12 hour light and the 12 hour dark intervals for each treatment group throughout the 10 day treatment period.

TABLE 4

MEAN DIFFERENCES IN FOOD CONSUAPTION (no. of pellets) AND STANDARD DEVIATIONS FOR EACH 12 HOUR LIGHT AND 12 HOUR DARK PERIOD FOR EACH TREATHENT GROUP ON EACH OF THE TEN TREATMENT DAYS

\begin{tabular}{|c|c|c|c|c|c|c|c|c|c|c|}
\hline & 1 & $\begin{array}{c}\text { Basel1 } \\
2\end{array}$ & ne 3 & $\operatorname{REM}_{4}$ DeE & $\underset{5}{\text { rivation }}$ & 6 & $\begin{array}{c}\text { Racovery } \\
7\end{array}$ & 8 & 9 & 10 \\
\hline $\begin{array}{r}\text { RSD } \\
\text { Sd }\end{array}$ & $\begin{array}{r}238.0 \\
\pm 51.6\end{array}$ & $\begin{array}{l}221.0 \\
\$ 117\end{array}$ & $\begin{array}{r}114.8 \\
\pm 64.9\end{array}$ & $\begin{array}{r}92.6 \\
+67.5\end{array}$ & $\begin{array}{r}143.8 \\
\pm 32.2\end{array}$ & $\begin{array}{r}155.4 \\
\pm 54.4\end{array}$ & $\begin{array}{r}222.8 \\
+94.9\end{array}$ & $\begin{array}{l}201.4 \\
\pm 133\end{array}$ & $\begin{array}{l}248.0 \\
\pm 57.7\end{array}$ & $\begin{array}{r}248.6 \\
+76.8\end{array}$ \\
\hline $\begin{array}{l}\text { WC } \\
\text { sd }\end{array}$ & $\begin{array}{r}379.8 \\
\pm 71.6\end{array}$ & $\begin{array}{r}355.2 \\
\pm 52.0\end{array}$ & $\begin{array}{l}148.0 \\
\pm 109\end{array}$ & $\begin{array}{r}251.2 \\
\pm 62.2\end{array}$ & $\begin{array}{l}346.6 \\
\pm 194\end{array}$ & $\begin{array}{l}250.0 \\
\pm 125\end{array}$ & $\begin{array}{l}325.4 \\
\pm 74.0\end{array}$ & $\begin{array}{r}304.8 \\
\pm 41.8\end{array}$ & $\begin{array}{r}345.4 \\
+42.6\end{array}$ & $\begin{array}{r}356.2 \\
\pm 19.3\end{array}$ \\
\hline $\begin{array}{l}D C \\
\text { sd }\end{array}$ & $\begin{array}{r}264.2 \\
\pm 89.2\end{array}$ & $\begin{array}{r}245.4 \\
\pm 97.3\end{array}$ & $\begin{array}{r}308.3 \\
\pm 65.4\end{array}$ & $\begin{array}{l}324.0 \\
\pm 133\end{array}$ & $\begin{array}{r}322.2 \\
\pm 71.2\end{array}$ & $\begin{array}{r}348.8 \\
\pm 82.8\end{array}$ & $\begin{array}{r}361.4 \\
\pm 73.3\end{array}$ & $\begin{array}{r}342.0 \\
\pm 59.8\end{array}$ & $\begin{array}{r}363.4 \\
\pm 38.8\end{array}$ & $\begin{array}{r}326.0 \\
\pm 67.4\end{array}$ \\
\hline
\end{tabular}


REM and Feeding

The data presented in Table 4 were first analyzed by computing a three (treatments) by ten (days) mixed factor ANOVA, and the results of this analysis are summarized in Appendix $\mathrm{D}$. Expected significant main effects for treatments $(\underline{F}(2,12)=4.98, \underline{p}<.05)$ and for days $(\underline{F}(9,108)=10.57, \underline{p}<.01)$ were computed, as was a significant interaction $(\underline{F}(18,108)=5.29, \underline{p}<.01)$. Additional post hoc ANOVAs (also summarized in Appendix D) performed on the data for each treatment day revealed significantly smaller light/dark differences for the REM deprived group throughout RSD and on the first and last two recovery days. Thus, these data suggest that REM deprived rats have smaller light/dark differences in food consumption than untreated animals, and these light/dark differences remain somewhat disturbed subsequent to the termination of RSD.

\section{Discussion}

An important aim of this study was to examine changes in food consumption due to RSD while minimizing possible confounding factors (e.g., undue stress indicated by bodyweight loss) that were present in previous studies (Bergmann, et al., 1984; Elomaa \& Johansson, 1980). As evidenced by the present data, this primary objective was achieved. The REM deprived animals maintained a consistent bodyweight throughout the RSD period and they gained weight at a rate equal to that of the control animals during the 
REM and Feeding

recovery period.

Contrary to the Bergmann, et al. (1984) and Elomaa \& Johansson (1980) studies, no differences between the REM deprived rats and the untreated control animals in total daily food consumption were found. This finding, when considered together with the bodyweight data, suggests that RSD does not facilitate greater food consumption in rats. While this finding does not provide support for Vogel's (1979) assertion that RSD potentiates primary drive-linked behavior, these results suggest possible important effects of RSD upon the cyclic behavior of these animals.

During night hours, normal rats are hyperphagic and during the light hours, the period of general hypoactivity, rats typically eat much less (Le Magnen \& Devos, 1970). Thus, there are usually large differences in food consumption between the light and dark periods. While the administration of RSD did not increase the total food consumption of the animals in this study, it did disrupt their normal $1 \mathrm{igh}$ /dark eating pattern. This food intake disturbance is demonstrated by the smaller light/dark differences in food consumption of the REM deprived rats (Table 4). Food consumption in these animals was redistributed so that they ate more food than the untreated controls during the light period (Table 3) and less food than the controls during the dark hours. This finding is in line with other studies (Elomaa, 1981; Johansson \& 
REM and Feeding

Elomaa, 1986) in which the light/dark difference in meal size was abolished during RSD.

The most apparent explanation for the greater light period food intake in these animals is that the REM deprived rats were simply more active than the control animals during the 12-hour light intervals. When measuring activity, Bergmann, et al. (1984) showed that REM deprived rats had $36 \%$ increase in total nuchal EMG vs. $11 \%$ for control rats. However, this explanation should not be viewed as discounting a RSD effect on eating behaviors since, as is shown in Table 4, the animals continued to eat less during the dark hours of the post treatment recovery period. As a consequence of this, the light/dark differences in food consumption for the REM deprived rats remained smaller than controls' throughout recovery. It is believed that these data suggest a carry-over effect of a cycle shift that occurred as a function of RSD.

Hence, this present study does not support assertions that RS is specifically involved in the regulation of primary drive linked-behaviors in that RSD did not increase food consumption in the animals of this study. However, as noted, the shift in the eating behavior of the RSD animals seems at least in part to be a consequence of RSD potentiated changes in energy and if this is true, then RS does, to some extent, seem to be involved in the cyclic occurrence of food intake. These data are consistent with Vogel's more general 
REM and Feeding

21

hypothesis, i.e., that RSD increases the level of drive. Perhaps the most significant finding of this study is the suggestion that RSD altered the cyclic nature of food consumption in a manner that influenced these behaviors during the entire recovery period. Both the physiological mechanisms and the behavioral parameters of this effect remain to be determined. 
REM and Feeding

\section{REFERENCES}

Bergmann, B., Kushida, C., Hennessy, C. C., Winter, D., \& Rechtschaffen, A. (1984). Paradoxical sleep deprivation in the rat: II. Energy consumption. Sleep Research, 13, 185 .

Bowersox, S. S., Baker, T. I., \& Dement, W. C. (1984). Rapid eye movement sleep and its relationship to feeding behavior in the adult cat. Physiology \& Behavior, 32, 378-381.

Dement, W. C. (1965). Recent studies on the biological role of REM sleep. American Journal of Psychiatry, 122, 404-408.

Elomaa, E. (1981). The light/dark difference in meal size in the laboratory rat on a standard diet is abolished during REM sleep deprivation. Physiology \& Behavior, 26, 487-493.

Elomaa, E. (1985). Effects of rapid eye movement sleep deprivation on the feeding behavior in the laboratory rat with a description of the cuff pedestal technique. Acta Physiologica Scandinavica, 125 (Suppl. 545), 1-35.

Elomaa, E., \& Johansson, G. G. (1980). Rapid eye movement stage of sleep participates in the generation of the nocturnal meal pattern in the rat. Physiology \& Behavior, 24, 331-336.

Hicks, R. A., Gomez, S., Gonzales, L., Kuroda, M., Orme, N. J., \& Reyes, J. (1981). REM sleep deprivatión reduces emotionality in female rats. Bulletin of the Psychonomic Society, 22, 689-692.

Hicks, R. A., Hirshfield, C., Humphrey, V., Lauber, A., Giampaoli, J., \& Hawkins, J. (1981). REM sleep deprivation and food competition in male rats. Physiology \& Behavior, 26, 245-247.

Hicks, R. A., \& Moore, J. D. (1979). REM sleep deprivation diminishes fear in rats. Physiology \& Behavior, 22, 689692 .

Johansson, G. G., \& Elomaa, E. (1986). Effects of partial food restriction on nocturnal meal size and feeding speed are counteracted by concurrent REM sleep deprivation in the rat. Behavioral Brain Research, 20, 275-280.

LeMagnen, J., \& Devos, M. (1970). Metabolic correlates of the meal onset in the free food intake of rats. Physiology \& Behavior, 5, 805-814. 
REM and Feeding

Mendelson, W. B., Guthrie, R. D., Frederick, G., \& Wyatt, R. $J_{\text {. , (1974) }}$. The flower pot technique of rapid eye movement (REM) sleep deprivation. Pharmacology, Biochemistry, and Behavior, 2 , 553-556.

Seigal, J. M., (1975). REM sleep predicts subsequent food intake. Physiology \& Behavior, 15, 399-403.

Vogel, G. W. (1979) A motivational function of REM sleep. In R. Drucker-Colin, M. Shkurovich, \& M. D. Sterman (Eds.) The Function of sleep (pp. 233-250). New York: Academic Press. 
REM and Feeding

Appendix A

Summary Table of Analysis of Bodyweight Data

\begin{tabular}{lcccc} 
Source of Variance & SS & dF & Ms & F \\
\hline Treatments & 12606 & 2 & 6303 & 1.52 \\
Subs/Treatments & 49733 & 12 & 4144.42 & \\
Days & 16090 & 9 & 1787.78 & $53.09 *$ \\
Treatments * Days & 4468 & 18 & 248.22 & 7.37 * \\
Days * Subs/Treatments & 3637 & 108 & 33.68 & \\
Total & 86534 & 149 & & \\
*p<.01 & & & & \\
\hline
\end{tabular}


REM and Feeding

Post Hoc Analyses of Treatments at each Day

for Bodyweight Data

\begin{tabular}{|c|c|c|c|c|}
\hline Source of Variance & SS & $\mathrm{dF}$ & Ms & $\mathrm{F}$ \\
\hline $\begin{array}{l}\text { Treatments \& Day }{ }^{1} \\
\text { Subs/Treatments \& Day } 1\end{array}$ & $\begin{array}{l}1290.72 \\
5316.12\end{array}$ & $\begin{array}{r}2 \\
12\end{array}$ & $\begin{array}{l}645.36 \\
443.06\end{array}$ & 1.46 \\
\hline $\begin{array}{l}\text { Treatments a Day } 2 \\
\text { Subs/Treatments a Day } 2\end{array}$ & $\begin{array}{r}446.19 \\
6198.01\end{array}$ & $\begin{array}{r}2 \\
12\end{array}$ & $\begin{array}{l}223 \cdot 1 \\
516 \cdot 5\end{array}$ & $<1$ \\
\hline $\begin{array}{l}\text { Treatments a Day } 3 \\
\text { Subs/Treatments @ Day } 3\end{array}$ & $\begin{array}{l}1270.18 \\
5476.42\end{array}$ & $\begin{array}{r}2 \\
12\end{array}$ & $\begin{array}{l}635.09 \\
456.37\end{array}$ & 1.39 \\
\hline $\begin{array}{l}\text { Treatments \& Day } 4 \\
\text { Subs/Treatments \& Day } 4\end{array}$ & $\begin{array}{l}1189.23 \\
5815.92\end{array}$ & $\begin{array}{r}2 \\
12\end{array}$ & $\begin{array}{l}594.61 \\
484.66\end{array}$ & 1.23 \\
\hline $\begin{array}{l}\text { Treatments \& Day } 5 \\
\text { Subs/Treatments } 2 \text { Day } 5\end{array}$ & $\begin{array}{l}1928.69 \\
4985.88\end{array}$ & $\begin{array}{r}2 \\
12\end{array}$ & $\begin{array}{l}964.35 \\
415.49\end{array}$ & 2.32 \\
\hline $\begin{array}{l}\text { Treatments @ Day } 6 \\
\text { Subs/Treatments \& Day } 6\end{array}$ & $\begin{array}{l}2629.73 \\
4932.68\end{array}$ & $\begin{array}{r}2 \\
12\end{array}$ & $\begin{array}{r}1314.73 \\
411.06\end{array}$ & 3.20 \\
\hline $\begin{array}{l}\text { Treatments \& Day } 7 \\
\text { Subs/Treatments \& Day } 7\end{array}$ & $\begin{array}{l}2070.04 \\
5026.69\end{array}$ & $\begin{array}{r}2 \\
12\end{array}$ & $\begin{array}{r}1035.02 \\
418.89\end{array}$ & 2.47 \\
\hline $\begin{array}{l}\text { Treatments \& Day } 8 \\
\text { subs/Treatments \& Day } 8\end{array}$ & $\begin{array}{l}1896.34 \\
4965.23\end{array}$ & $\begin{array}{r}2 \\
12\end{array}$ & $\begin{array}{l}948.17 \\
413.77\end{array}$ & 2.29 \\
\hline $\begin{array}{l}\text { Treatments a Day } 9 \\
\text { Subs/Treatments a Day } 9\end{array}$ & $\begin{array}{l}2241.95 \\
4944.46\end{array}$ & $\begin{array}{r}2 \\
12\end{array}$ & $\begin{array}{r}1120.97 \\
412.04\end{array}$ & 2.72 \\
\hline $\begin{array}{l}\text { Treatments \& Day } 10 \\
\text { Subs/Treatments \& Day } 10\end{array}$ & $\begin{array}{l}2110.18 \\
5708.21\end{array}$ & $\begin{array}{r}2 \\
12\end{array}$ & $\begin{array}{r}1055.09 \\
475.68\end{array}$ & 2.22 \\
\hline
\end{tabular}


REM and Feeding

Appendix B

Summary Table of Analysis of 24 hour Food Consumption Data

\begin{tabular}{lcccc} 
Source of Variance & SS & dF & Ms & F \\
\hline Treatments & 13686 & 2 & 6843 & $<1$ \\
Subs/Treatments & 122600 & 12 & 10216.67 & \\
Days & 285996 & 9 & 31777.33 & $8.36 *$ \\
Treatments * Days & 141696 & 18 & 7872.00 & 2.07 \\
Days * Subs/Treatments & 410632 & 108 & 3802.15 & \\
Total & 974610 & 149 & & \\
\hline
\end{tabular}

$\star \mathrm{p}<.05$ 
REM and Feeding

Appendix C

Summary Table of Analysis of Light Period Food Consumption F Source of Variance $\quad$ SS $d F \quad$ Ms

\begin{tabular}{|c|c|c|c|c|}
\hline Treatments & 122455.3 & 2 & 61227.65 & $6.76 *$ \\
\hline Subs/Treatments & 108552.6 & 12 & 9046.05 & \\
\hline Days & 217626.6 & 9 & 24180.73 & $21.05 *$ \\
\hline Treatments * Days & 143631.1 & 18 & 7979.51 & $6.95 *$ \\
\hline Days * Subs/Treatments & 124073.4 & 108 & 1148.83 & \\
\hline Total & 716339 & 149 & & \\
\hline $\begin{array}{l}\star \mathrm{p}<.05 \\
\text { Summary Table of Anal }\end{array}$ & ysis of Da & $\mathrm{ck} \mathrm{Pe}$ & od Food Co & sumption \\
\hline F $\quad$ Source of & Variance & & $d F$ & Ms \\
\hline Treatments & 151565 & 2 & 75782.5 & $6.20 *$ \\
\hline Subs/Treatments & 146651 & 12 & 12220.92 & \\
\hline Days & 41154 & 9 & 4572.67 & 1.40 \\
\hline Treatments * Days & 67601 & 18 & 3755.61 & 1.15 \\
\hline Days * Subs/Treatments & 354021 & 108 & 3277.97 & \\
\hline Total & 760992 & 149 & & \\
\hline
\end{tabular}


REM and Feeding

28

Appendix D

Summary Table of Analysis of Light/Dark Differences

\begin{tabular}{lcrcc} 
Source of Variance & SS & dF & Ms & F \\
\hline Treatments & 524226 & 2 & 262113 & $4.98 *$ \\
Subs/Treatments & 631517 & 12 & 52626.42 & \\
Days & 221349 & 9 & 24594.33 & $10.57 *$ \\
Treatments * Days & 221747 & 18 & 12304.11 & $5.29 *$ \\
Days * Subs/Treatments & 251259 & 108 & 2326.47 & \\
Total & 1849825 & 149 & & \\
\hline
\end{tabular}

$\star p<.05$ 
REM and Feeding

Post hoc Analyses of Treatments at each Day

for Light/Dark Difference Data

\begin{tabular}{|c|c|c|c|c|}
\hline Source of Variance & ss & $\mathrm{dF}$ & Ms & $\mathrm{F}$ \\
\hline $\begin{array}{l}\text { Treatments a Day } 1 \\
\text { Subs/Treatments \& DAY } 1\end{array}$ & $\begin{array}{l}56928.4 \\
70833.6\end{array}$ & $\begin{array}{r}2 \\
12\end{array}$ & $\begin{array}{r}28464.2 \\
5902.8\end{array}$ & $4.82 *$ \\
\hline $\begin{array}{l}\text { Treatments \& Day }{ }^{2} \\
\text { Subs/Treatments \& Day } 2\end{array}$ & $\begin{array}{l}51101.73 \\
103898\end{array}$ & $\begin{array}{r}2 \\
12\end{array}$ & $\begin{array}{r}25550.87 \\
8658.17\end{array}$ & 2.95 \\
\hline $\begin{array}{l}\text { Treatments \& Day } 3 \\
\text { Subs/Treatments a Day } 3\end{array}$ & $\begin{array}{l}107421.73 \\
82012\end{array}$ & $\begin{array}{r}2 \\
12\end{array}$ & $\begin{array}{r}53710.87 \\
6834.33\end{array}$ & $7.86 *$ \\
\hline $\begin{array}{l}\text { Treatments @ Day } 4 \\
\text { Subs/Treatments @ Day } 4\end{array}$ & $\begin{array}{l}97495.6 \\
147934\end{array}$ & $\begin{array}{r}2 \\
12\end{array}$ & $\begin{array}{l}48747.8 \\
12327.83\end{array}$ & $3.95 *$ \\
\hline $\begin{array}{l}\text { Treatments \& Day } 5 \\
\text { Subs/Treatments \& Day } 5\end{array}$ & $\begin{array}{l}122582.93 \\
175908.8\end{array}$ & $\begin{array}{r}2 \\
12\end{array}$ & $\begin{array}{l}61291.47 \\
14659.07\end{array}$ & 4.18 * \\
\hline $\begin{array}{l}\text { Treatments a Day } 6 \\
\text { Subs/Treatments a Day } 6\end{array}$ & $\begin{array}{r}93523.6 \\
1050663.4\end{array}$ & $\begin{array}{r}2 \\
12\end{array}$ & $\begin{array}{l}46761.8 \\
87555.28\end{array}$ & $<1$ \\
\hline $\begin{array}{l}\text { Treatments \& Day } 7 \\
\text { Subs/Treatments Day } 7\end{array}$ & $\begin{array}{l}51721.2 \\
79349.2\end{array}$ & $\begin{array}{r}2 \\
12\end{array}$ & $\begin{array}{r}25860.6 \\
6612.43\end{array}$ & $3.91 *$ \\
\hline $\begin{array}{l}\text { Treatments e Day } 8 \\
\text { Subs/Treatments Day } 8\end{array}$ & $\begin{array}{l}53072.93 \\
92834\end{array}$ & $\begin{array}{r}2 \\
12\end{array}$ & $\begin{array}{r}26536.47 \\
7736.17\end{array}$ & 3.43 \\
\hline $\begin{array}{l}\text { Treatments a Day } 9 \\
\text { Subs/Treatments Day } 9\end{array}$ & $\begin{array}{l}38546.53 \\
26606.4\end{array}$ & $\begin{array}{r}2 \\
12\end{array}$ & $\begin{array}{c}19273.27 \\
2217.2\end{array}$ & $8.69 *$ \\
\hline $\begin{array}{l}\text { Treatments a Day } 10 \\
\text { Subs/Treatments \& Day } 10\end{array}$ & $\begin{array}{l}30800.93 \\
43270\end{array}$ & $\begin{array}{r}2 \\
12\end{array}$ & $\begin{array}{r}15400.47 \\
3605.83\end{array}$ & $4.27 *$ \\
\hline
\end{tabular}

